\title{
LIST OF MAPS AND PLATES
}

\author{
MAPS
}

1 The Black Volta region today xii

2 North-Western District of the Northern Territories of the Gold Coast, 1905

3 Northern Territories of the Gold Coast, Provinces and Districts, 1907

4 Carte du Haut-Niger au Golfe de Guinée, L. H. Binger, 1887-9 77

5 The Hinterland of the Gold Coast, G. E. Ferguson, $1893 \quad 78$

6 North-Western District of the Northern Territories of the Gold Coast, 1905 (detail)

7 Northern Province by Tribal Areas, $1928 \quad 106$

8 Territoire dagari, Paternot, $1949 \quad 161$

9 The new districts of the Upper West Region, 1989

10 Tribes in Ghana, $1960 \quad 258$

PLATES

1 Lawra Confederacy divisional chiefs, c.1939 109

2 Nandom Naa Imoru and chiefs, 1940s 124

3 Gratiano Naabesog and his wife in Tarkwa, 1950s 148

4 Lawra Naa J. A. Karbo, $1949 \quad 177$

5 Abayifaa Karbo, Member of Parliament, 1954

6. Jirapa Naa Bapenyiri Yelpoe, $1962 \quad 206$

7 K. Y. Baloro as teacher, Lambussie, 1950s 223

8 Nandom Naa K. P. Polkuu, 1960s 225

9 Chiefs during the Kakube festival, Nandom, 1994 